\title{
SOSIALISASI MENINGKATKAN IMUNITAS KESEHATAN IBU DI MASA PANDEMI DI LINGKUNGAN RW 07 KARANGBESUKI KOTA MALANG
}

\author{
Wilyati Agustina, Suhartatik, Titik Purwati \\ IKIP Budi Utomo \\ wilyanti310875@gmail.com, suhartatiksih@gmail.com,titikpurwati62@gmail.com
}

\begin{abstract}
In 2020, the outbreak of a new virus that shocked the world, namely Coronavirus Disease (Covid 19). There are some ways to survive from the pandemic such as obeying government instructions and increase the immunity of body. The purpose of the community service is to provide counseling or social outreach, as well as provide education related to improving maternal health and immunity during the pandemic. The activities of Community Service cover several stages. First, coordinating about the Community Service Agenda with the Head of Neighborhood and Citizens Associations. Second, the executor team prepare some materials of socialization. Third, the executor team conduct the educational outreach. In conclusion, improving maternal health and immunity can be reached by consuming healty food, providing healthy life, and avoiding stress.
\end{abstract}

Keywords: Socialization, maternal health and immunity, pandemic

\section{ANALISIS SITUASI}

Pada tahun 2020, merebaknya virus baru yang menggemparkan dunia, yaitu Coronavirus Disease (COVID-19). Asal usul virus ini diketahui berasal dari Wuhan, China. Virus tersebut ditemukan pada akhir tahun 2019, dan 65 negara dipastikan terjangkit virus tersebut (PDPI, 2020 dalam Yuliana, 2020). Menurut data WHO per 6 Agustus 2021, secara keseluruhan terdapat 200.840.180 kasus terkonfirmasi Covid-19 dan 4.265.903 kematian. Hingga 4 Agustus 2021, total 3.984.596.440 orang telah divaksinasi (WHO, 2021). Hingga saat ini, pengobatan virus ini terus berlanjut dan menyebar secara misterius. 65 negara sudah terjangkit virus ini, termasuk Indonesia. Situasi di masyarakat pada masa pandemi Covid 19 membutuhkan penyuluhan bersama untuk melawan Covid 19. Kesehatan memiliki arti yang sangat penting untuk kehidupan, dan setiap orang mempunyai hak untuk menjaganya. Pentingnya arti hidup sehat telah menjadikan kesehatan sebagai kebutuhan hidup manusia yang utama disamping kebutuhan hidup lainnya. Pemenuhan kebutuhan kesehatan merupakan hak dari setiap orang bagaimana yang tercantum didalam "Declaration of Human Right" Pasal 25 ayat 1 dalam Moenir (1995: 35)[2] "Selain mencuci tangan, memakai masker dan menjaga jarak, makan makanan juga penting untuk menjaga kekuatan dan tetap sehat.. Karena anggapan orang tentang makanan bergizi seringkali salah, sebagian orang mengira makanan bergizi itu pasti mahal, padahal anggapan tersebut salah. Salah satu cara untuk menjaga daya tahan tubuh yaitu dengan mengkonsumsi suplemen yang mengandung zat-zat yang diperlukan tubuh [3]. Beberapa hal yang dapat dilakukan adalah:

Makan makanan bergizi, makan makanan bergizi, makan makanan bergizi, terutama sumber vitamin $\mathrm{C}$ dan vitamin $\mathrm{E}$, dapat meningkatkan daya tahan tubuh terhadap penyakit. 
Mengkonsumsi sumber zat gizi langsung dari makanan akan lebih baik dibandingkan didapat dari suplemen tambahan. Akan tetapi dalam kondisi tubuh memerlukan tambahan bisa juga dengan mengonsumsi suplemen vitamin dan mineral.

Olah raga teratur dapat menangkal masuknya virus pada tubuh. Olah raga tidak harus diluar rumah. Dalam kondisi pandemic, olah raga bisa juga dilakukan di rumah.

Sering cuci tangan dengan sabun pada air mengalir menjadi faktor yang sangat penting untuk membunuh virus yang menempel di tangan. Mencuci tangan selama kurang lebih 20 detik perlu dibudayakan agar kita tidak tertulari dan tidak menulari. Mencuci tangan dengan hand sanitizer menjadi alternatif kedua jika tidak tersedia tempat cuci tangan dengan sabun. Kandungan alkohol dalam hand sanitizer menurut WHO minimal 60 $\%$. Sangat dianjurkan jika setiap kali kita keluar rumah selalu membawa hand sanitizer pada tas atau saku [4]

Hindari menyentuh wajah kebiasaan menyentuh area segitiga wajah, yaitu mata, hidung dan mulut, karena melalui pintu inilah virus corona masuk pada tubuh manusia.

Pakai masker, virus corona dapat menular melalui droplet, yaitu cairan yang keluar bersamaan ketika batuk, bersin atau percikan air liur ketika berbicara. Oleh sebab itu menggunakan masker dapat melindungi orang lain yang mungkin kita tulari atau mengcegah menularan dari orang lain pada kita. Banyak yang salah ketika menggunakan masker, misalnya membuka masker ketika bicara.[5]

Istirahat cukup, tidur yang cukup dan berkualitas kurang lebih 6-8 jam dapat meningkatkan imunitas tubuh. Hindari begadang malam.

Etika batuk dan bersin, jangan menutup mulut dengan tangan ketika batuk atau bersin, tapi gunakan tissue, sapu tangan atau tutup mulut dengan menggunakan lipatan lengan.

Saat ini marak kegiatan desinfeksi baik yang digerakkan oleh lembaga maupun inisiatif masyarakat. Fasilitas umum seperti bandara, pasar, stasiun, terminal dan lainnya perlu dilakukan disinfeksi secara rutin.

\section{METODE PELAKSANAAN}

Pelaksanaan kegiatan pengabdian masyarakat dilakukan dengan memberikan Sosialisasi Meningkatkan Imunitas Kesehatan Ibu Di Masa Pandemi Di Lingkungan RW 07 Karangbesuki Kota Malang.

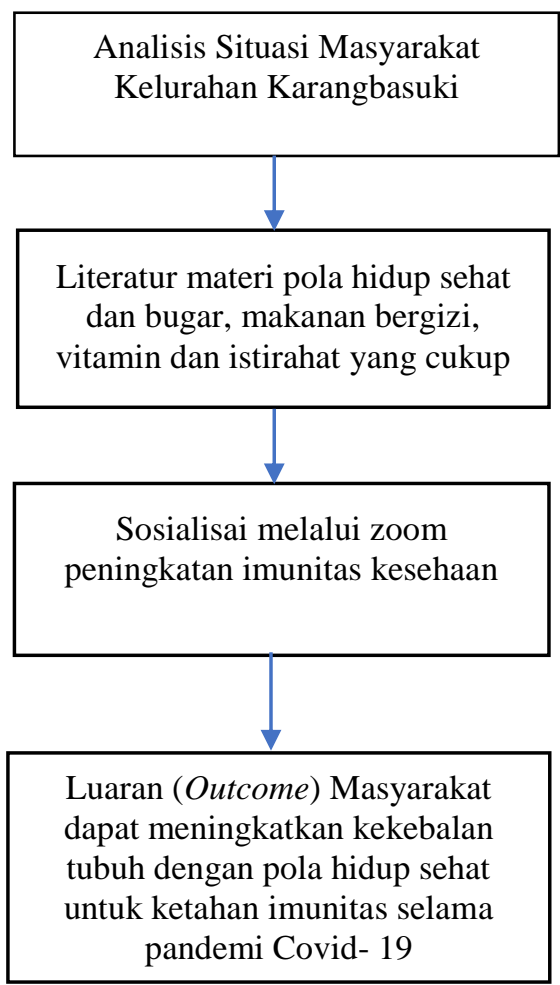

Gambar 1. Bagan Pelaksanaan kegiatan PKM dilakukan

\section{HASIL DAN PEMBAHASAN}

Pengabdian masyarakat ini bertujuan untuk Sosialisasi Meningkatkan Imunitas Kesehatan Ibu Di Masa Pandemi Di Lingkungan RW 07 Karangbesuki Kota Malang Kegiatan dalam program ini meliputi: 
1. Persiapan awal mengadakan observasi lokasi Persiapan dengan lokasi dilakukan pada bulan September 2021 oleh tim pengabdian Kegiatan ini dilakukan untuk mengetahui kondisi lingkungan masyarakat.

2. Wawancara dengan Ketua PKK. Berdasarkan hasil wawancara dengan ketua PKK RW 07 didapatkan informasi analisis situasi dan kondisi di lokasi.

3. Pengajuan ijin pelaksanaan pelatihan Membuat surat perijinan untuk Sosialisasi Meningkatkan Imunitas Kesehatan Ibu Di Masa Pandemi Di Lingkungan RW 07 Karangbesuki Kota Malang, diawali pembuatan Surat izin pengabdian kepada pihak masyarakat serta P2M IKIP Budi Utomo Malang.

4. Persiapan sarana dan prasarana pelatihan

Dalam pelaksaan Sosialisasi Meningkatkan Imunitas Kesehatan Ibu Di Masa Pandemi Di Lingkungan RW 07 Karangbesuki Kota Malang, dibutuhkan persiapan sarana dan prasarana yang mendukung proses sosialisasi. Sarana dan prasarana yang mendukung meliputi, materi yang dilengkapi dengan audio pendukung, materi sosialisasi, Laptop, PPT , microphone.

5. Pelaksanaan pelatihan

Pelaksanaan penyuluhan Sosialisasi Meningkatkan Imunitas Kesehatan Ibu Di Masa Pandemi Di Lingkungan RW 07 Karangbesuki Kota Malang Kerjasama berjalan sesuai dengan yang diharapkan baik dan lancar. Acara dimulai dengan silahturahmi kunjungan ketua pkk RW 07. Warga sangat antusias dan tertarik dengan materi pelatihan serta banyak pertanyaan yang diberikan warga karena rasa keingintahuan yang tinggi. Warga juga diperlihatkan video terkait dengan video perilaku hidup sehat.

6. Refleksi pelaksanaan pelatihan

Setelah dilakukan penyuluhan potensi Sosialisasi Meningkatkan Imunitas Kesehatan Ibu Di Masa Pandemi Di Lingkungan RW 07 Karangbesuki Kota Malang, tim pengabdian melakukan refleksi terhadap pelaksanaan pelatihan untuk memperbaiki kekurangankekurangan pada saat pelaksanaan pelatihan, harapannya agar kedepannya menjadi lebih baik dan memuaskan, serta bisa dilakukan secara kontinyu dan konsisten di beberapa tempat.

7. Materi Sosialisasi Meningkatkan Imunitas Kesehatan Ibu Di Masa Pandemi Di Lingkungan RW 07 Karangbesuki Kota Malang.

a. Mengonsumsi Makanan Sehat dan Minum Air Putih yang cukup

b. Banyak mengonsumsi sayur dan buah, menghindari makanan yang mengandung bahan kimia, serta konsumsi air putih (minimal 8 gelas/hari atau sekitar 2 liter)

c. Mengonsumsi protein (nabati maupun hewani) dan karbohidrat dalam jumlah yang sesai angka kecukupan gizi yang dianjurkan (AKG) untuk menabah asupan nutrisi.

d. Menghindari/mengurangi konsumsi makanan yang mengandung bahan pengawet (salah satunya mengandung natrium/sodium), yang dapat menyumbang peningkatan tekanan darah (selain garam), karena natrium dapat mengikat air beban kerja ginjal semakin meningkat.

e. Mengonsumsi Vitamin $\mathrm{C}$ yang berfungsi meningkatkan daya tahan tubuh, kesehatan jaringan kulit, peredaran darah dan syaraf otak, dan sebagai antioksidan. 
f. Mengonsumsi Vitamin D yang berfungsi keseatan tulang dan otot, mencegah penyakit kronis, meningkatkan system kekebalan, memperbaiki suasana hati.

g. Memiliki Berat badan ideal, obesitas/berat berlebih akan meningkatkan resiko munculnya penyakit tertentu seperti penyakit jantung, stroke, diabetes.

h. Tingginya jumlah lemak dalam tubuh inilah yang penting untuk menilai resiko seseorang terkena berbagai penyakit tidak menular.

i. Berolahraga secara teratur

j. Mengurangi makanan dan minuman manis, seperti soft frink, kue, es krim.

k. Istirahat cukup namun berkualitas jauh lebih baik disbanding waktu istirahat yang lama namun tidak berkualitas.

1. Tidur yang dianjurkan sekitar 6-8 jam/hari

m. Waktu tidur yang baik adalah sekitar pukul 9 atau 10 malam

n. Kurang tidur, menyebabkan hormon gherlin meingkat yang merangsang rasa lapar.

o. Mengendalikan stres

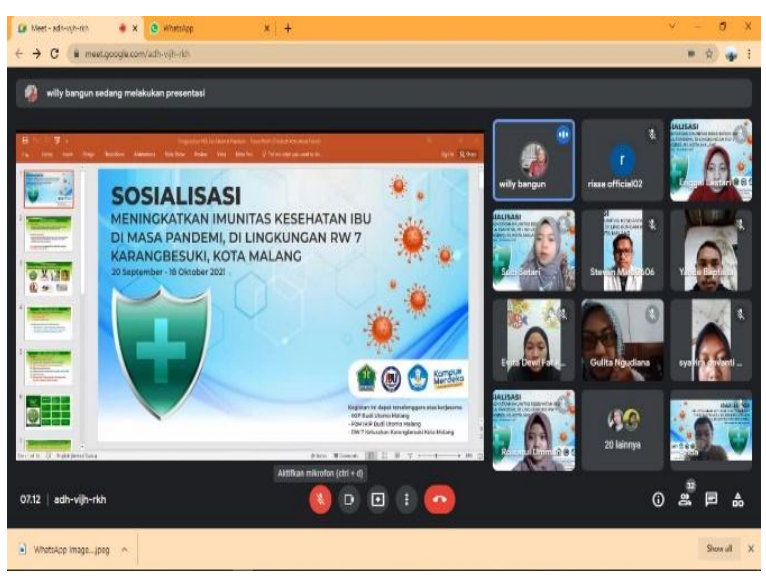

Gambar 2a. Pelaksanaan Sosialisai melalui Zoom Meeting

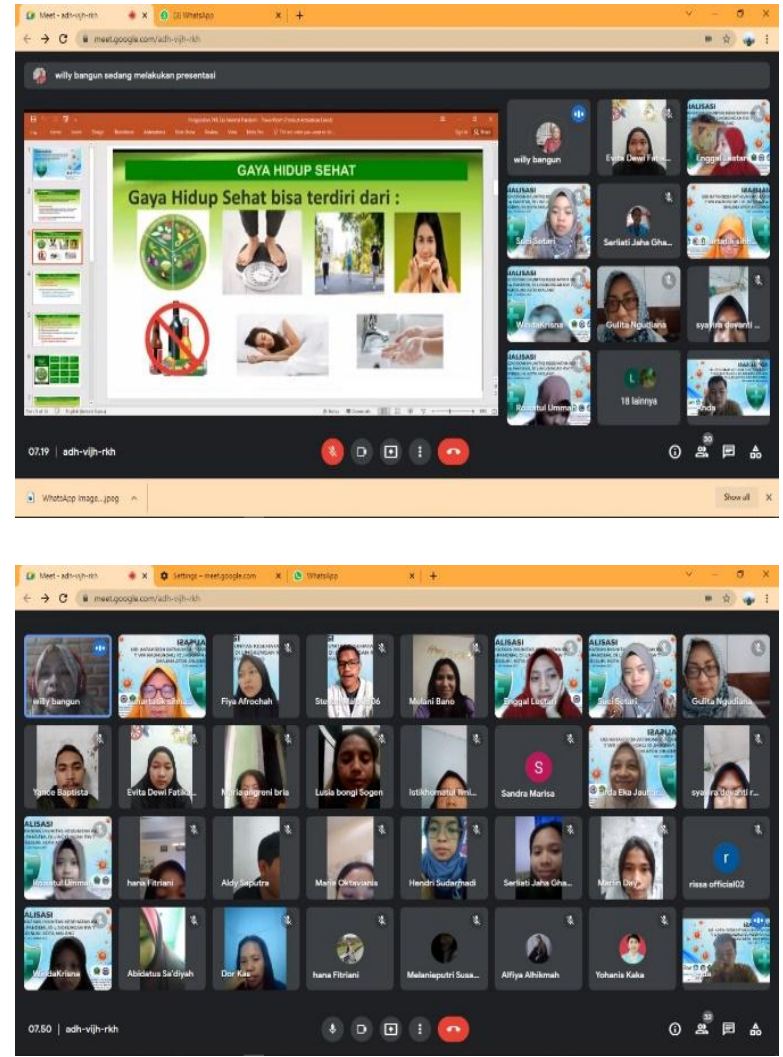

Gambar 2b. Pelaksanaan Zoom Meeting

\section{KESIMPULAN}

Pola hidup sehat adalah kegiatan yang dilakukan tidak secara instan harus penuh keteraturan sehingga menjadi kebiasaan gaya hidup keseharian dengan memperhatikan hal-hal yang mempengaruhi kesehatan fisik, antara lain pola makan, olahraga, dan istirahat yang cukup maupun kesehatan psikis dengan cara menghindari stres. Manajemen waktu pola pikir akan menyebabkan hidup jauh dari stress. Menerapkan pola hidup sehat sebagai kewajiban akan merubah pola dalam kehidupan sehari-hari dan memberikan banyak manfaat bagi tubuh manusia.

Bahkan, jika diterapkan dengan benar, efek positif yang dirasakan akan bertahan lama dan dapat mencegah datangnya berbagai penyakit tidak menular dari penyakit ringan hingga penyakit kronis. Oleh karena itu, menjaga kesehatan sedini mungkin akan memberikan dampak yang 
besar ketika di usia lanjut. Syarat utama bagi seseorang untuk menikmati kebahagiaan dalam hidup ini adalah kesehatan fisik dan mental.

\section{Ucapan Terima Kasih}

Rasa syukur kami ucapkan kepada segenap pihak yang mendukung suksesnya PKM kami yang berjudul "Sosialisasi Meningkatkan Imunitas Kesehatan Ibu Di Masa Pandemi Di Lingkungan Rw 07 Karangbesuki Kota Malang"

Kepada:

1. Rektor IKIP Budi Utomo, Dr Nurcholis Sunuyeko, M.Si

2. Ketua P2M, Dr Titik Purwati, M.M

3. Ibu Ketua RW 07 Karangbesuki Kota Malang

4. Ibu-Ibu PKK RT di RW 07 Karangbesuki Kota Malang

\section{DAFTAR PUSTAKA}

Yuliana. Corona virus diseases (Covid 19); Sebuah tinjauan literatur. Wellness and Healthy Magazine, vol 2 no 1. Februari 2020. hal 187 - 192. e-ISSN: 2656-0062 dan p-ISSN: 2655- 9951.

Hodgetts, TJ, Mackway-Jones (Eds). 2000

Major Incident edicalManagement and Support: the practicle approach. (5th)

Azwar, A. 1994 Standart Dan Mutu Pelayanan Medis. Majalah Kesehatan

Dara Maulidini Akbar \& Zuhrina Aidha.(2020). Perilaku Penerapan Gizi Seimbang Masyarakat Kota Binjai Pada Masa Pandemi Covid.3(1), 15-21

Afifah, MahardiniNur (2020). Panduan Pola Makan Bergizi dan Seimbang Pandemi Covid-19. 